\title{
A CUSTOMER PERCEPTION TOWARDS ONLINE SHOPPING AND OFFLINE SHOPPING
}

\author{
${ }^{* 1}$ M. Farzana Banu, ${ }^{2}$ Dr. Jayam \\ ${ }^{*}$ Research Scholar, Dr.MGR Educational and Research Institute, Maduravoyal, Chennai \\ ${ }^{2}$ Professor and Head, Department of Human Resource Management, Dr.MGR Educational \\ and Research Institute, Maduravoyal, Chennai \\ ${ }^{*}$ Email: mfarzanabanu061@gmail.com \\ ${ }^{2}$ Email: jayamjayam659@gmail.com
}

\begin{abstract}
The foremost aim of this research is to inspect the customer's insights about online \& offline shopping also test the satisfaction level of customers about the shopping criteria and the respective study is held in Chennai. However, rapid growth has emerged in the retail marketing sector in regards to digital shopping \& direct shopping. In this case, the current research tells certain scenarios, firstly, to study the customer satisfaction that is to check whether they are interested in offline or online shopping, secondly, customer attraction that is what mode (online, offline) makes them attracted, thirdly, observation of the customer feedbacks about the shopping methods. The methodology adopted is collection of primary data from 25 male and 25 female customers and analyze it using descriptive analysis, and chi-square test. To conclude, from the study conducted on Customer perception towards Online shopping is good when compared to Offline shopping and there is significant increase in Online shopping.
\end{abstract}

Keywords: Online \& Offline shopping, Customer Insights

\section{INTRODUCTION}

The research aims to study the perception of the customers with respect to the direct shopping and digital shopping conducted in the Chennai area. However, when compared with offline shopping methods, online shopping plays a significant role in the rapid growth of today's digital evolution in regard the purchase priorities. So as a result, the prominent goal of the research is about exposure to online shopping methods. From the online perspective, the pricequality is affected the consumer's trust. However, the entire view about online shopping gives customers a freshly enthusiastic touch and attractive. Also because of the digital evolution nature, online mode provides one roof access to its customer this ability attracts more customers upon online shopping. The main attraction of this is considered to be it has huge varieties of consumer products in that way everyone accesses it and buy from anywhere in the world.

\section{REVIEW OF LITERATURE:}

Taruna [2018] represented that Internet has changed the lot in the authentic way of buying goods online. In this current trend of buying goods, online has grown significantly that changed people's minds from offline mode to online mode because of the lifestyle changes. Everyone here working in Information technology sectors, due to its working load people did not get time 
to buy their stuff offline instead they chosen online to get their things done quickly. Moreover, every automobile sector had interested in digitally introducing systems. Additionally, customers did not just blindly buy things online also with the current pricing features they also compared its prices from various online shopping sites and also they tend to compare sales provided, etc. Moreover, E-commerce is another name for online shopping which tells the consumers whoever wished to buy things online directly from the seller with the help of any of the web browsers. Compared to other modes of shopping online provided numerous advantages firstly, it saves enough time, in that way everyone can be able to order their things from anywhere, secondly, it has a huge variety of products available, in direct shopping this considered to be difficult to get our things from various shops. and lot more advantages are considered. The key objective of this study is to validate the consumer's perspective on online shopping modes. Furthermore, this research utilized a Quantitative approach to analyze its objectives. By using Questionnaires the data of this research has been composed. However, this research also investigates the affecting factors over online shopping such as age factor, payment methods, and gender criteria[1].

Muhammed Muntaqheem, Satish D Raiker, [2018] narrated that, going shopping has emerged a lot in the current trend of influencing technology, in this way compared to the traditional physical shopping methods online trends offers various features and advantages as well. To attain the maximum lifts, the current trend takes the center phase among the retail marketers in the way they integrated two methods. This study aims to get compared direct physical store shopping with digital shopping also compare the consumer's behaviors over these shopping methods. Moreover, the statistics showed that male shoppers do more shopping in the online mode than store shopping. But still, regarding the safer payment methods, shopping malls define more preferences. Though online mode provides various advantages, it failed to gain people's trust, feel and touch of the products, by this offline mode gains more preferences. In our research, we identify that Jabong and Flipkart play a significant role in digital shopping, and strongly believe that online mode would be growing significantly in the future[2].

Raja Sarkar, Sabyasachi Das, [2017] expressed that retail sectors are considered to be one of the fast-emerging sectors in the current technology. This holds majorly 10 percent of the country's GDP and plays a significant role in the development of the economy. As statistics data says, Indian market value attained to be reached by over 600 American dollars also our Indian retail sector bags top the fifth position in the world's regarding economical growth. Moreover, Indian consumers are very conscious about their products in such a way that, they have preferences about online and offline shopping methods. But still, two of the modes have both their advantages and disadvantages. Firstly, online mode got a huge variety of products, they provide huge offers $\&$ discounts, also provides an extended facility for delivering products to homes in a way we don't need to travel more distance to buy things, also it would function $24 / 7$, then it provides the facility of giving customer ratings, whereas, offline mode helps to validate the quality of the product and touch that doesn't come in online mode. Nevertheless, the customer would go for both the shopping at some point of times according to their choices, as a result, it showed the various behavior of the two-mode shoppings. So this research provides some clarity about different choices of customers over offline and digital shopping behaviors[3]. 
D.Suthamathi, Mr.S.Jeeva [2020] demonstrated consumers' valued opinions while using online and physical shopping in which they recognized and processed the conceptual addressing towards both the shopping methods. Furthermore, there is an analysis in which both types of buyers are examined to see how the value is built in both modes. However, it aims to recognize the influential factors involved in both online and offline progressions. Additionally, the risks involved in the online modes are wrong delivery of the different product rather than the actual product, lacking in timely delivery, also the quality is not up to the standards for the price sometimes. On the other hand, offline shopping risks factors are purchasing time, negotiating the prices, and very few varieties of choices. The research showed that, price perception over consumers, the quality of the services, and purchasing intentions while using both modes. The key objective of this study is considered to be identifying the major variances between both the modes of customers in terms of technological factors, availability of use, and behaviors of the customers. Additionally, based on major information retrieved from the users this research is analyzed[4].

JiHyo Moon 1, Yunseon Choe 2,3 and HakJun Song 4,[2021] have been narrated that before the covid-19 pandemic people were interacted face to face by that we can communicate with each other and buy things physically. But the world has changed a lot to do offline shopping. This study demonstrated the characteristics of the user's shopped during the covid pandemic. In pandemic life, everyone resides online especially conducting meetings and buying things online. Additionally, the participants are also tested on how often they use the online while in the pandemic also to analyze which determinants will be utilized while in this situation. This research contributed that the deeper observation of the consuming structures of the users both offline and online[5].

Hence there is a need for the study of Customer Buying Behavior towards online and offline shopping in Chennai.

\subsection{Objective of the research}

- The research aims to identify what attracts a consumer to buy Online and Offline shopping.

- The research aims to study the satisfaction level of customers about Online and Offline shopping.

- The aim is to analyze customer remarks about Online and Offline shopping.

- The aim is to build a strong image of Online and Offline shopping.

- The aim is to study customer perception towards online and offline shopping.

\section{RESEARCH METHODOLOGY}

It's considered to be a hard process to meet and accumulate all of the data from the entire people's population. As a result, some of the researchers process the method called convenient sampling methods. According to the convenience of the researchers, the sampling units get classified in this method. A detailed study of the main information is accumulated with a sample size of fifty people where there are 25 men and 25 women with help of well-structured questionnaires. Secondary data was collected through books, Websites, and Magazines. 


\subsection{Tools of study}

The data were collected from the respondents were analyzed using various statistical tools such as descriptive analysis, and chi-square test.

\subsection{Statistical analysis}

Based on a well-structured questionnaire the following data are obtained and analyzed which are given in table 1 .

Table 1: Customer perception towards online shopping and offline shopping

\begin{tabular}{|c|c|c|c|c|c|c|c|c|}
\hline S.No & Description & $\mathbf{N}$ & Mean & SD & $\begin{array}{c}\text { Chi- } \\
\text { Square }\end{array}$ & df & $\begin{array}{l}\text { Asymp. } \\
\text { Sig. }\end{array}$ & Result \\
\hline 1 & Age & 50 & 2 & 0.93 & $11.280^{\mathrm{a}}$ & 3 & 0.01 & Significant \\
\hline 2 & Gender & 50 & 0.5 & 0.51 & $.000^{\mathrm{b}}$ & 1 & 1.00 & $\begin{array}{c}\text { Not } \\
\text { Significant }\end{array}$ \\
\hline 3 & Marital Status & 50 & 1.36 & 0.48 & $3.920^{\mathrm{b}}$ & 1 & 0.05 & Significant \\
\hline 4 & Occupation & 50 & 2.88 & 1.06 & $5.840^{\mathrm{a}}$ & 3 & 0.12 & $\begin{array}{c}\text { Not } \\
\text { Significant }\end{array}$ \\
\hline 5 & Monthly Income & 50 & 2.24 & 1.06 & $3.280^{\mathrm{a}}$ & 3 & 0.35 & $\begin{array}{c}\text { Not } \\
\text { Significant }\end{array}$ \\
\hline 6 & $\begin{array}{c}\text { Do you prefer online or } \\
\text { offline shopping? }\end{array}$ & 50 & 1.48 & 0.50 & $.080^{\mathrm{b}}$ & 1 & 0.78 & $\begin{array}{c}\text { Not } \\
\text { Significant }\end{array}$ \\
\hline 7 & $\begin{array}{l}\text { what do you usually } \\
\text { purchase in online } \\
\text { shopping? }\end{array}$ & 50 & 2.04 & 1.01 & $9.840^{\mathrm{a}}$ & 3 & 0.02 & Significant \\
\hline 8 & $\begin{array}{l}\text { what do you usually } \\
\text { purchase in offline } \\
\text { shopping? }\end{array}$ & 50 & 1.9 & 0.89 & $16.720^{\mathrm{a}}$ & 3 & 0.00 & Significant \\
\hline 9 & $\begin{array}{c}\text { what is your satisfaction } \\
\text { level when you do online } \\
\text { shopping? }\end{array}$ & 50 & 2.1 & 0.97 & $11.280^{\mathrm{a}}$ & 3 & 0.01 & Significant \\
\hline 10 & $\begin{array}{c}\text { what is your satisfaction } \\
\text { level when you do } \\
\text { offline shopping? }\end{array}$ & 50 & 2.34 & 0.89 & $13.840^{\mathrm{a}}$ & 3 & 0.00 & Significant \\
\hline 11 & $\begin{array}{c}\text { why would you choose } \\
\text { online vs offline } \\
\text { shopping? }\end{array}$ & 50 & 2.64 & 1.10 & $.880^{\mathrm{a}}$ & 3 & 0.83 & $\begin{array}{c}\text { Not } \\
\text { Significant }\end{array}$ \\
\hline 12 & $\begin{array}{c}\text { Do you feel confident } \\
\text { when you purchase from } \\
\text { online? }\end{array}$ & 50 & 0.8 & 0.40 & $18.000^{\mathrm{b}}$ & 1 & 0.00 & Significant \\
\hline 13 & $\begin{array}{l}\text { How many times you go } \\
\text { for offline shopping? }\end{array}$ & 50 & 2.42 & 1.13 & $.400^{\mathrm{a}}$ & 3 & 0.94 & $\begin{array}{c}\text { Not } \\
\text { Significant }\end{array}$ \\
\hline 14 & $\begin{array}{l}\text { In which factor will } \\
\text { affect you to buy in } \\
\text { online? }\end{array}$ & 50 & 2.62 & 1.16 & $1.680^{\mathrm{a}}$ & 3 & 0.64 & $\begin{array}{l}\text { Not } \\
\text { Significant }\end{array}$ \\
\hline
\end{tabular}




\begin{tabular}{|c|c|c|c|c|c|c|c|c|}
\hline 15 & $\begin{array}{l}\text { Tick the reason why you } \\
\text { choose offline product? }\end{array}$ & 50 & 2.46 & 1.15 & $.400^{\mathrm{a}}$ & 3 & 0.94 & $\begin{array}{c}\text { Not } \\
\text { Significant }\end{array}$ \\
\hline 16 & $\begin{array}{l}\text { Do offline shopping have } \\
\text { a range of product? }\end{array}$ & 50 & 2.54 & 1.09 & $1.680^{\mathrm{a}}$ & 3 & 0.64 & $\begin{array}{l}\text { Not } \\
\text { Significant }\end{array}$ \\
\hline 17 & $\begin{array}{l}\text { Have you ever made } \\
\text { online shopping? }\end{array}$ & 50 & 0.8 & 0.40 & $18.000^{\mathrm{b}}$ & 1 & 0.00 & Significant \\
\hline 18 & $\begin{array}{c}\text { Does Online shopping } \\
\text { provide you latest } \\
\text { product that are } \\
\text { available? }\end{array}$ & 50 & 0.74 & 0.44 & $11.520^{\mathrm{b}}$ & 1 & 0.00 & Significant \\
\hline 19 & $\begin{array}{l}\text { How often you use } \\
\text { internet for online } \\
\text { shopping? }\end{array}$ & 50 & 2.32 & 1.13 & $6.000^{\mathrm{a}}$ & 3 & 0.11 & $\begin{array}{l}\text { Not } \\
\text { Significant }\end{array}$ \\
\hline 20 & $\begin{array}{l}\text { In shopping which is a } \\
\text { convenient mode of } \\
\text { payment? }\end{array}$ & 50 & 2.82 & 0.94 & $9.040^{\mathrm{a}}$ & 3 & 0.03 & Significant \\
\hline \multicolumn{9}{|c|}{$\begin{array}{l}\text { a. } 0 \text { cells }(0.0 \%) \text { have expected frequencies less than } 5 \text {. The minimum expected cell frequency } \\
\text { is } 12.5 .\end{array}$} \\
\hline & $(0.0 \%)$ have expec & & $\begin{array}{r}\text { es le } \\
\text { is }\end{array}$ & han & 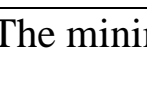 & & & ncy \\
\hline
\end{tabular}

Source: Primary data and developed by the researcher

As per table 1, the following Findings are obtained. Using descriptive analysis and Chi-square test to test the hypothesis the following results are obtained.

- In terms of Age group 18 are in $18-30,17$ are in $31-45,12$ are in 46-60, 3 are in $61-75$ and none are 75 and above. There is a significant difference in age groups.

- Regarding Gender 25 are Male and 25 are Female taken into consideration for the study. There are no such variations between Gender and both are considered to be the same.

- On Marital status 32-are Married and 18 are Unmarried. There is a significant difference between Marital status

- Regarding Occupation 7 are from the government, 10 are doing Business, 15 are Professional and 18 are Self-employed. There is no significant difference among various occupations.

- Regarding Monthly Income in Rs. 15 are Below 15000, 16 are between 15001 - 30000, 11 are between 30001- 50000, 8 are between 50001-75000 and none are above 75000 and above. There is no significant difference between the monthly incomes of the consumers.

- When customers were asked about the preference of online or offline shopping 26 of them said yes and 24 said no. Hence there is no significant difference in customers' preference of online or offline shopping.

- When asked about usual purchases in online shopping, 18 said Groceries, 18 said Clothing,8 said Electronics, 6 said Others. Hence there is a significant difference in usual purchases in online shopping

- When asked about usual purchases in offline shopping, 21 said Groceries, 14 said Clothing,14 said Electronics, 1 said Others. Hence there is a significant difference in usual purchases in offline shopping 
- When asked about the level of satisfaction while doing online shopping, 15 said Average, 21 said satisfied, 8 said very satisfied and 6 said dissatisfied. There is a significant difference in the level of satisfaction while doing online shopping.

- When asked about the level of satisfaction while doing offline shopping, 8 said Average, 23 said satisfied, 13 said very satisfied and 6 said dissatisfied. There is a significant difference in the level of satisfaction while doing offline shopping.

- When asked about choosing online vs offline shopping, 10 said Not a social person, 12 said Time efficiency, 14 said It's easier, 14 said More products online. There is no significant difference in choosing online vs offline shopping.

- When asked with customers about feeling confident when they purchase online, 40 said Yes and 10 said No. There is a significant difference in customers feeling about purchasing online.

- When asked about How many times they go offline shopping, 14 of them said every month, 12 of them said Regular, 13 of them said seldom, 11 of them said once in a week. There is no significant difference in no. of times customers go for offline shopping.

- When asked about which factor will affect them to buy online, 11 said Advertisement,13 said social media, 10 said Internet, 16 said all the above. There are no such prominent variations in the total of factors that affect them to buy online.

- When asked to tick the reason why they choose offline products 14 prefer to touch the product,11 said it is Better return policies, 13 said there are store discounts, 12 said all the above. There is no significant difference in choosing an offline product.

- When asked whether offline shopping have a range of product, 10 of them Strongly agreed, 16 of them Agreed, 11 of them are neutral, 13 of them Disagreed. There is no significant difference in offline shopping have a range of products,

- When asked whether they have made online shopping 40 said yes and 10 said no. There is a significant difference in doing online shopping.

- When enquired about Does Online shopping provide you latest products that are available, 37 of them said yes, 13 of them said no. There is a significant difference in Online shopping which provides the latest products.

- When discussed How often they use the internet for online shopping, 14 of them said very often, 18 of them said often, 6 of them said Sometimes, 12 of them said Never. There is no significant difference in using the internet for online shopping.

- When requested to inform in shopping which is a convenient mode of payment 5 of the customers said spot cash, 12 of the customers said by card, 20 of the customers said by scan, 13 of the customers said cash on delivery. There is a significant difference in the convenient mode of payment while shopping.

\section{SUGGESTIONS AND CONCLUSION}

Customer perception towards Online and Offline shopping are studied in Chennai, Tamil Nadu with 25 male and 25 female customers. There is a difference in age groups. There is no difference between Gender and both are the same. There is a difference between Marital status. There is no difference among various occupations. There is no difference between the monthly incomes of the consumers. There is no difference in customers' preference for online or offline 
shopping. There is a difference in usual purchases in online shopping. There is a difference in usual purchases in offline shopping. There is a difference in the level of satisfaction while doing online shopping. There is a difference in the level of satisfaction while doing offline shopping. There is no difference in choosing online vs offline shopping. There is a difference in customers feeling about purchasing online. There is no difference in no. of times customers go for offline shopping.

There is no difference in no. of factors which affect them to buy in online. There is no difference in choosing an offline product. There is no difference in offline shopping having a range of products. There is a difference in doing online shopping. There is a difference in Online shopping which provides the latest products. There is no significant difference in using the internet for online shopping. There is a significant difference in the convenient mode of payment while shopping.

To conclude, from the study conducted on Customer perception towards Online and Offline shopping there is a significant increase in customer behavior towards Online.

\section{REFERENCES}

[1]. Taruna [2017], International Journal of Engineering Research \& Technology (IJERT), NCIETM - (Volume 5 - Issue 11).

[2]. Muhammed Muntaqheem, Satish D Raiker, [2018], A Study on Consumer Behavior towards Online and Offline Shopping, OCT 2019 | IRE Journals | Volume 3 Issue 4

[3]. Raja Sarkar, Sabyasachi Das, [ 2017], Online Shopping vs Offline Shopping: A Comparative Study IJSRST | Volume 3 | Issue 1 |(17) (PDF) Online Shopping vs Offline Shopping : A Comparative Study. Available from: https://www.researchgate.net/publication/334942312_Online_Shopping_vs_Offline_Shoppin g_A_Comparative_Study [accessed Oct 15 2021].

[4]. D. Suthamathi, Mr.S. Jeeva [2020], Online Shopping Vs Offline Shopping Customer Preference in Salem District International Journal of Scientific \& Technology Research Volume 9, Issue 02, February 2020 ISSN 2277-8616 5394 Ijstr@2020 www.ijstr.org

[5]. Jiho Moon 1, Yunseon Choe 2,3 and HakJun Song 4, [2021], Determinants of Consumers' Online/Offline Shopping Behaviors during the COVID-19 Pandemic International Journal of Environmental Research and Public Health 